YAK 347.4

DOI https://doi.org/10.32837/chc.v0i40.385

\author{
Гуйван Петро Амитрович, \\ кандидат юриАичних наук, заслужений юрист України, \\ професор \\ Полтавського інституту бізнесу \\ ORCID ID: 0000-0003-3058-4767
}

\title{
ТЕОРЕТИЧНІ АСПЕКТИ СТРОКІВ ДIÏ ОХОРОННОГО ЦИВІЛЬНОГО ПРАВОВІДНОШЕННЯ
}

Постановка проблеми. ПоряА з широким розумінням поняття "охорона цивільних прав", яке включає у себе всю сукупність заходів організаційного, економічного, політичного характеру тощо, спрямованих на створення умов Аля зАійснення суб'єктивного права, у цивілістиці використовується більш вузьке розуміння поняття "захист". Це визначені законом заходи, що спрямовані на віАновлення чи припинення порушення цивільних прав. Власне, вони і становлять зміст цивільноправового визначення захисту суб'єктивних прав. Право на захист можна сформулювати як наявну у правоволодільця можливість застосувати заходи правоохоронного змісту Аля віАновлення свого порушеного права. Вона реалізується через зАійснення (часто в примусовому порядку) саме охоронно-правової зАатності права Ао реалізації у разі його порушення. Отже, властивість примусової реалізації притаманна не регулятивному, а охоронному зобов'язанню [1, с. 12]. СправАі, після порушення регулятивного зобов'язання не може бути й мови про його подальше існування. Взаємин, які б опосередковували нормальний, правомірний розвиток суб'єктивного права та віАповіАного юридичного обов'язку, вже немає. Але виникає охоронне зобов'язання, якраз його елемент - охоронне суб'єктивне право триватиме після порушення і може бути належним чином реалізоване, в тому числі і за допомогою Аержавного юрисаикційного органу - суду. Саме про тривалість такого відношення у вигляАі позовного Аомагання йдеться у ч. 1 ст. 261 цКУ. Саме ж охоронне право, притаманне вірителю, не залежить віА спливу позовної Аавності, хоча після такого спливу і втрачає примусову властивість.
Аналіз останніх досліАжень і публікацій. У наукових працях питання виникнення та перебігу охоронних правовідносин, зокрема, стосовно їхніх темпоральних характеристик, отримали висвітлення у роботах таких учених, як М.А. Гурвич, О.С. Йоффе, В.В. Ауць, Є.А. Крашенінніков, Є.М. Мотовіловкер, Б.Б. Черепахін, П.М. Рабінович, Г.Я. Стоякін та інші. Ними було проведено вивчення змісту взаємин на рівні "кредиторборжник" у різних станах взаємодії, включаючи фазу правопорушення та визначення правового статусу контрагентів при цьому. ЗАійснено вивчення темпоральної складової частини права особи на примусову реалізацію права після його порушення. Утім питання не $є$ визначеним остаточно, про це свідчить велика кількість різнобачень як у теоретичних концепціях, так і у практичній площині. Не набула остаточного та усталеного вигляау правова позиція, за якою охоронно-правове відношення виникає не внаслідок існування регулятивного, а в результаті його порушення зобов'язаною особою. Наукове обґрунтування цієї тези становить мету статті.

ВикиаА основного матеріалу. Найбільш яскравим проявом заійснення охоронного повноваження особи, що виникає в межах віАповіАного правовіАношення у разі порушення суб'єктивного права, вважається преА'явлення позову. Власне, судова вимога є лише засобом Аля реалізації передбаченої законодавством можливості. І ця можливість стосується виключно примусового зАійснення охоронного повноваження. Реалізація домагання як спосіб Аосягнення такого результату призводить Ао поАальшого примусового зАійснення охоронного повноваження. Тож 
цілком зрозуміло, що Аомагання ніяк не може бути особливим станом охоронюваного віАношення. Таким чином, відбувається розділення вимоги про усунення порушення та правової піАстави Аля такої вимоги. Тезу про те, що право на позов є окремим віА регулятивного цивільного права охоронним повноваженням особи, піАтримують окремі сучасні АосліАники проблеми [2, с. 106-109]. Охоронних повноважень різного змісту, спрямованих на захист права у разі його порушення, у носія може бути декілька. Звісно, за кожною з таких вимог, якщо вони мають характер позовного Аомагання, віАбувається власний незалежний перебіг Аавнісного строку.

За великим рахунком такий справедливий піАхіА якраз і викликає найбільше заперечень та неприйняття у середовищі тих науковців, котрі обстоюють концепцію про примусову реалізацію судом саме регулятивного права. На заперечення тези про припинення існування регулятивного правовідношення після правопорушення наводиться те обґрунтування, що, скажімо, Аобровільне виконання зобов'язаною стороною обов'язку, котрий випливає з правовіАносин, у яких право кредитора припинилося, буде протирічити закону і має визнаватися неправомірним. Все отримане після такого виконання кредитором піАлягає поверненню особі, що виконала зобов'язання. А^е то, як указують опоненти, абсурА, ми часто маємо практичні ситуації, коли боржник повертає гроші із запізненням, піАрядник виконує роботу несвоєчасно, орендар пропускає строк користування чужим майном. Пода^ьше ж виконання простроченого обов'язку $€$ належним.

Подібні міркування щодо реально існуючих ситуацій, на перший погляА, піАтверАжують позиції апологетів теорії, згіАно з якою регулятивне суб'єктивне матеріальне право продовжується і після закінчення часу своєї дії, встановленого сторонами чи нормативно [3, с. 86]. Так, у різних Аоктринальних публікаціях та судовій практиці часто трапляються висловлювання на кшталт: “зобов' язання (обов'язок) діє і після строку, визначеного у зобов'язанні, та продовжується Ао повного його виконання". Такий підхіА теоретично, як прави^о, не обґрунтовується, у кращому разі застосовуються рудименти застарілої концепції про перетворення непорушеного суб'єктивного права у інший свій стан - порушений. Та це в жоАному разі не пояснює продовження тривалості регулятивного права. I то найгірше. Бо ж тоді виникає цілком закономірне питання: навіщо взагалі встановлювати час Аля зАійснення зобов'язання, якщо певний обов'язок, а значить, і кореспонауюче йому право, існують вічно, Аопоки не припиняться у встановленому у главі 50 ЦКУ поряАку? Саме такий піАхіА призводить сучасних теоретиків та практиків до нехтування темпоральними критеріями регулятивного правовідношення, тим більше, він не сприяє усвідомленню науковою спільнотою того факту, що строк є обов'язковою істотною умовою права, складовою частиною його внутрішнього змісту, сплив якого свіАчить про вичерпаність останнього.

Насправді подібні підходи Є антинауковими і Ауже шкіАливими, бо фактично спотворюють реальну картину сприйняття конкретних зобов'язальних взаємин, які відбуваються у суспільстві. Вкотре повторимо, що після закінчення строку на виконання регулятивного зобов'язання воно вичерпується за своїм змістом і припиняється. Не існує вже суб'єктивного регулятивного права вірителя та віАповідного обов'язку боржника. Натомість із самого юридичного факту - правопорушення виникає охоронне віАношення, котре, нагадаємо, може реалізовуватися як у судовій формі (позовній), так і несудовій. Ао змісту такого охоронного зобов'язання, окрім Аодаткових вимог кредитора, пов'язаних із порушенням (штрафні санкції, відшкодування шкоди, припинення правовіАношення тощо), входить і вимога стосовно виконання обов'язку в натурі. Так ось, усі вказані повноваження та кореспонАуючі їм охоронні обов'язки порушника регулятивного права (а не тільки основний обов'язок, як часто помилково вважається) і будуть існувати Ао їхнього повного виконання. Такий невизначений строк Аії охоронного зобов'язання стосується виключно несудових його форм (це, на наше переконання, $€$ недоліком чинного законодавства, і ми пропонуємо все-таки встановити строки погашення охоронних несудових зобов'язань [4, с. 185]). Якщо ж кредитор вибере судову форму зАійснення свого охоронного права за подібним зобов'язанням, то час Аля початку його реалізації за Аопомогою звернення Ао державного юридичного органу буде обмеженим і регулюватиметься тривалістю позовної Аавності за відповіАними вимогами.

Отже, хоча, на перший погляА, у разі примусового виконання обов'язку відбувається реалізація суб'єктивного права після його порушення, насправді виникає Аекілька охоронно-правових відносин різного змісту, а правоволоділець як учасник таких віАносин може скористатися чи не 
скористатися своїми захисними правами. I мише одним із повноважень, що витікають 3 охоронного зобов'язання, є повноваження на виконання обов'язку в натурі, в тому числі за допомогою державного примусу. ЗАійснення такого охоронного права відбувається за Аопомогою чи без Аопомоги юрисдикційного органу. I хоча одночасно, зАавалося б, реалізується регулятивне віАношення, захист права відбувається через реалізацію однакового з ним за змістом віАношення охоронного. Справа в тому, що зі спливом часу на належне виконання зобов'язання у кредитора також існує право вимоги до боржника щодо виконання відповіАного обов'язку, існує і кореспондуючий обов'язок боржника. Але виконання зобов'язання після збігу встановленого на це строку не можна вже вважати належним, а саме зобов'язання слід кваліфікувати як таке, що не виконується належним чином. Цивільно-правові віАносини за участю боржника і кредитора перестають бути регулятивними. Виникають нові відносини, пов'язані з необхідністю захисту порушеного матеріального права, і навіть Аобровільне виконання обов'язку, який за змістом $€$ тотожним тому, що входив Ао склаАу регулятивного відношення, насправді є реалізацією охоронного.

3 огляду на викладене та з урахуванням юридичної сутності коментованого явища, правильним із методологічної точки зору буде тверАження, що регулятивний юриАичний обов'язок особи, що виник із зобов'язального відношення, не продовжується після прострочення виконання, а припиняється. Охоронно-правові ж обов'язки, що виникають віА моменту прострочення, тривають Ао повного їх виконання, якщо інше не встановлено актами законодавства України. Отже, ми Аоводимо, що регулятивне право вимоги щодо виконання боржником обов'язку в натурі віАрізняється віА охоронно-правового Аомагання такого ж змісту. Ця віАмінність полягає в тому, що регулятивне повноваження спрямоване на Аобровільне виконання зобов'язаною особою свого обов'язку. Зазначене право, як і кореспонАуючий йому обов'язок, вхоАить Ао склаАу регулятивного правовіАношення, його існування обмежується не Аавнісним строком, а встановленою тривалістю взаємин. Водночас охоронне суб'єктивне право існує мише в межах віАповіАного охоронного зобов'язання, а його зАатність Ао примусової реалізації може бути забезпечена шляхом преА'явлення віАповіАного позову упроАовж позовної Аавності і після цього вілповідне охоронне повноваження може бути зАійснене через посереАництво юрисАикційного органу.
Разом із тим у літературі була висловлена думка про те, що примус Ао виконання може зАійснюватися іноді в межах регулятивного правовіАношення [5, с. 206]. При цьому автори такої тези вважають, що охоронне віАношення виникає мише тоді, коли в результаті порушення суб'єктивного права у сторін з'являються нові права та обов'язки. Це характерно Аля відношення, змістом якого є зобов' язання з віАшкодування збитків. Якщо ж правопорушення не породжує Аодаткових матеріальних зобов'язань, а впливає лиш на спосіб виконання обов'язку, який існував раніше, то охоронного відношення взагалі не виникає, а захист порушеного суб'єктивного права, в тому числі і примусово, відбувається в межах регулятивного правовідношення [6, с. 10, 11, 15]. НаприклаА, у разі примусового виконання передбаченого угодою обов'язку. 3 таким твердженням не можна погодитися і насамперед ось чому.

За своїм визначенням регулятивним $€$ таке правовіАношення, в межах якого віАбувається нормальне зАійснення суб'єктивного права та виконання юридичного обов'язку. Такий нормальний розвиток взаємодії учасників охоп^юється Аиспозицією правової норми або позитивним змістом Аоговору тощо. Тому якщо учасники цивільного віАношення Аотримуються встановлених за таких умов правил поведінки (а це, власне, і $€$ ознакою регулятивності віАносин), їхня повеАінка $€$ правомірною, що усуває необхідність захисних Аій, у тому числі і впливу держави на поведінку учасників правовідношення, що нормально розвивається. 3 іншого боку, коли нормальний розвиток цивільного правовідношення припиняється у зв'язку з невиконанням оАним із учасників покладеного на нього обов'язку, недотримання належних правил поведінки тягне порушення суб'єктивного цивільного права, захист якого з юридичного боку забезпечується через можливість реалізації охоронного права особи, в тому числі і шляхом застосування заходів державного примусу. Цивільно-правова санкція $€$ результатом реалізації у встановленому порядку охоронного права особи. Таким чином, можна стверджувати, що сама абстрактна можливість примусу $є$ стимулюючим чинником Аля регулятивного правовідношення [7, с. 202-203], хоча і не є складником його змісту, однак практичне зАійснення примусу можливе мише через реалізацію Аомагання, яке входить Ао складу охоронного віАношення. Оскільки, як бачимо, захисна функція реалізується через особливе охоронноправове віАношення, помилковим сліА визнати 
твердження, що невід'ємною складовою частиною суб'єктивного права поряд з повноваженням на власні та чужі дії $€$ можливість його примусового зАійснення за допомогою державних юрисАикційних органів [8, с. 108]. Така властивість не притаманна регулятивному суб'єктивному праву.

Позаяк охоронне суб'єктивне право входить Ао складу віАповіАного охоронного зобов'язального правовіАношення, його сутність, власне, залишається майже такою самою, як і сутність регулятивного. Праву уповноваженої особи стосовно вимагання (отримання) належної поведінки відповідає обов'язок зобов'язаної особи вчинити певне Аіяння. Та оскільки охоронне віАношення вже не відображає нормальний перебіг взаємин, оскільки воно розвивається після порушення, зАійсненого одним із учасників, тут уже не може бути мови про рафіновану рівність контрагентів. Отже, Ао змісту охоронного суб'єктивного права поряА із тими повноваженнями, що були у носія регулятивного, входить можливість застосування Аержавного примусу заАля його реалізації. Якщо у судовому чи несудовому порядку буде реалізовано охоронно-правову вимогу про виконання обов'язку в натурі, це, звісно, припинить певні охоронні віАносини. Але не всі. Так, прострочка у виконанні Аоговору поставки потягне виникнення охоронного віАношення, за яким покупець набуде можливості в примусовому порядку вимагати виконання зобов'язання в натурі, віАшкодування завданих збитків, стягнення неустойки тощо. Після подальшого виконання вже простроченого обов'язку охоронне правовіАношення щодо примусового реального виконання зобов'язання припиниться, але інші охоронні відносини збережуть свою Аію. Їх практична реалізація залежить віА багатьох факторів, у тому числі і віА перебігу відведеного законом проміжку часу на домагання.

Вказане загальне правило щодо входження Ао складу охоронного зобов'язання права кредитора на виконання боржником обов'язку в натурі має виключення, зокрема у разі, коли в результаті порушення подібне виконання стає неможливим. НаприклаА, коли втрачене майно, що піАлягає передачі. Як відомо, захист матеріального права в подібному випадку у вказаний спосіб є неможмивим. У зв'язку з цим можна зробити висновок, що охоронне правовіАношення, Ао змісту якого входить вимога про виконання обов'язку в натурі, в такому разі не виникає. Проте це зовсім не означає, що регулятивне право втратило захисну здатність. Якщо, скажімо, річ, що належить власнику, буде знищена іншою особою, право власності на неї припиниться. А^е при цьому з порушення відносин власності виникає інше - охоронне правовіАношення, змістом якого вже буде не право володіти, користуватися та розпоряАжатися річчю, а передбачена законом можмивість отримати відповідне віАшкодування. При цьому може трапитися, що регулятивне право утвориться з Аоговору, тоді як охоронна вимога, що виникає з порушення цього права, базуватиметься на положеннях нормативного акта. Скажімо, у разі знищення об'єкта оренди оренАар має повернути орендодавцеві його вартість. Регулятивне зобов'язання повернути річ у такому разі виникає з відповідного договору. Проте після Знищення речі у правоволодільця припиняється можливість вимагати ії повернення. Але з такого порушення умов Аоговору виникає охоронне віАношення, зміст якого полягає у праві на відшкодування вартості майна.

Інший приклаА - невиконання зобов'язаною особою обов'язку, який полягає в утриманні віА вчинення дії. НаприклаА, в абсолютних цивільних віАносинах невизначене коло осіб має утримуватися віА Аій, що перешкоджають власникові реалізувати свої повноваження. Звісно, коли Аія, що порушує право, вчинена, виникає охоронне зобов'язальне правовіАношення, Ао змісту якого входить зокрема можливість преА'явлення вимоги про усунення порушення. Та, якщо Ао моменту реалізації суб'єктивного охоронного права (Ао моменту звернення Ао суду) порушник припинить неправомірну Аію, охоронна вимога теж припиниться. Проте продовжуватимуть існувати інші захисні вимоги, ніж та, що витікала 3 регулятивного відношення та була спрямована на припинення порушення. Вони, скажімо, можуть полягати у відшкодуванні нанесеної порушенням шкоди. Таке відшкодування, як і попередня вимога, котра припинилася, перебуватиме у межах змісту віАповіАного охоронного правовіАношення [9, с. 128].

Заслуговує на увагу теза Б.Б. Черепахіна, згінно з якою в результаті порушення будь-якого абсолютного права (зокрема, права власності) між потерпілим правоволодільцем і порушником встановлюється такий же конкретний правовий зв'язок, як і в зобов'язанні, що характеризується визначеністю суб'єктного складу та змісту вимог. Інакше кажучи, на відміну віА регулятивних цивільних віАносин, охоронне правовіАношення завжАи має віАносний характер: правомочність правоволодільця віАповідає чітко визначеному обов'язку зобов'язаної 
особи (осіб). При цьому автор правильно віАзначає, що абсолютне правовідношення не трансформується у віАносне, аАже у правово^одільця 3 іншими суб'єктами, які не є порушниками його права, продовжують відбуватися взаємини абсолютного поряАку. 3 абсолютного відношення у разі продовження його існування виділяється відносне [10, с. 290]. Отже, ^ише виникненням у момент порушення права нового правовіАношення охоронного типу можна пояснити існування одночасно абсолютного та відносного відношення. Тому Б.Б. Черепахін, сам того не бажаючи, спростовує обстоювану ним теорію про існування особливого стану будь-якого суб'єктивного права на певній стадії його розвитку (у разі порушення).

Отже, з викладеного можемо Аійти висновку, що після порушення матеріального права суб'єкта цивільних відносин з'являється охоронне правовідношення. Його суб'єктний склаА може бути тим же, що і в регулятивному стані або іншим. Змістом нового правовідношення буде реалізація можливості юридичного захисту прав кредитора. Взаємини, що виникають, мають уже зовсім інший характер, вони будуть спрямовані на усунення порушення права, припинення неналежного виконання обов'язку, відшкодування збитків тощо, в тому числі і шляхом застосування Ао порушника заходів примусу. При цьому зміст визначення "охоронне право" значно ширший за термін "матеріальне право на позов" і не може зводитися виключно Ао останнього. Охоронні відносини виникають мише у разі правопорушення, при цьому незалежно віА того, чи вчиняє кредитор якісь захисні заходи. Поява охоронного віАношення тільки забезпечує властивість суб'єктивного права до захисту. у будь-якому разі визначення охоронного правовіАношення не тільки можливо, але й необхідно запровадити та використовувати у цивілістиці та у вітчизняному законодавстві, оскільки воно характеризує певний усталений тип цивільних правовідносин.

\section{NITEPATYPA:}

1. Мотовиловкер Е.Н. Юридическая ответственность и принуждение. Юридическая ответственность: общие проблемы и отраслевые особенности. Владивосток : Изд-во Дальневост. ун-та, 1990. С. 10-12.

2. Горовець С. Переривання позовної давності: сутність і призначення. Юридичний журнал. 2005. № 12. С. 102-111.

3. Новоселова Л.А. О правовых последствиях нарушения денежного обязательства. Москва. Вестник ВАС РФ. 1999. № 1 . С. 82-92.

4. Гуйван П.Д. Теоретичні питання строків у приватному праві : монографія. Харків : Право, 2014. 632 с.

5. Фатхуллин Ф.Н. Проблемы теории государства и права. Курс лекций. / Науч. ред.: Марченко М.Н. Казань : Изд-во Казан. ун-та, 1987. 336 с.тоякин Г.Я. Меры защиты в советском гражданском праве : автореф. дис. ... канд. юрид. наук. Свердловск, 1973. $18 \mathrm{c.}$

6. Кушерець Д.В. Охоронні правовідносини у сфері договірного права: теоретичні питання. Науковий вісник Міжнародного гуманітарного університету. Серія Юриспруденція. 2014. № 1. Том. 1. С. 201-203.

7. Александров Н.Г. Законность и правоотношения в социалистическом обществе. Москва : Госюриздат, 1955.176 с.

8. Осокина Г.Л. К вопросу о соотношении субъективного гражданского права и правомочия на его защиту (на примере субъективного права собственности). Вестник Томского гос. университета. 2012. № 360 (июль). С. 127-130.

9. Черепахин Б.Б. Труды по гражданскому праву / Научн. ред. С.С. Алексеев. Москва : Статут, 2001. 479 с.

\section{Гуйван Петро Амитрович}

\section{ТЕОРЕТИЧНІ АСПЕКТИ СТРОКІВ АІЇ ОХОРОННОГО ЦИВІАЬНОГО ПРАВОВІАНОШЕННЯ}

Ця стаття присвячена науковому досліАженню питання стосовно сутності та місця в межах цивільного правовіАношення суб'єктивного повноваження особи на захист свого порушеного права. ПіАкреслюється, що право на захист є наявною в уповноваженої особи можливістю застосувати заходи правоохоронного змісту Аля віАновлення свого порушеного права. Автор обстоює тезу, за якою після порушення регулятивного зобов'язання припиняється подальше існування регулятивного відношення. Взаємин, які б опосередковували нормальний, правомірний розвиток суб'єктивного права та відповіАного юридичного обов'язку, вже немає. Натомість виникає охоронне зобов'язання, якраз його елемент - охоронне суб'єктивне право триватиме після порушення і може бути належним чином реалізоване, в тому числі і за допомогою державного юрисликційного органу - суду. У такому контексті наводиться обґрунтована критика застарілої концепції стосовно можливості примусової реалізації судом саме регулятивного права. Наголошується, що після закінчення строку на виконання регулятивного зобов'язання воно вичерпується за своїм змістом і припиняється. Натомість із самого юридичного факту - правопорушення виникає охоронне відношення, котре може реалізовуватися як у судовій формі (позовній), так і несудовій. Ао змісту такого охоронного зобов'язання, окрім Аодаткових вимог кредитора, пов'язаних із порушенням (штрафні санкції, відшкодування шкоди, припинення правовідношення тощо), входить і вимога стосовно виконання обов'язку в натурі. В останньому випадку захист права відбувається через реалізацію однакового з регулятивним зобов'язанням за змістом відношення - охоронного. ААже виконання зобов'язання після збігу встановленого на це строку не можна вже вважати належним, а саме зобов'язання слід кваліфікувати як таке, що не виконується належним чином. При цьому практичне зАійснення примусу можливе лише через реалізацію Аомагання, яке входить Ао складу охоронного віАношення.

Киючові слова: охоронне віАношення, правопорушення, право на захист. 


\section{Guivan Petro}

\section{THEORETICAL ASPECTS OF THE TERM OF PROTECTION OF CIVIL LAW}

This article is devoted to the scientific study of the question of the nature and place within the civil legal relationship of the subjective authority of a person to protect her violated right. It is emphasized that the right to protection is available to the authorized person to apply law enforcement measures to restore her violated right. The author defends the thesis that after the violation of the regulatory obligation, the continued existence of the regulatory relationship ceases. There is no longer a relationship that would mediate the normal, lawful development of subjective law and the corresponding legal obligation. Instead, a protective obligation arises, and it is precisely its element - the protective subjective right will last after the violation and can be properly exercised, including with the help of the state jurisdiction - the court. In this context, there is a well-founded criticism of the outdated concept of the possibility of enforcement by the court of regulatory law. It is noted that after the expiration of the regulatory obligation, it is exhausted in its content and terminated. Instead, from the very legal fact - the offense arises a protective relationship, which can be implemented both in court (claim) and non-judicial. The content of this security obligation, in addition to the additional claims of the creditor related to the violation (penalties, damages, termination of employment, etc.), includes a requirement to perform the obligation in kind. In the latter case, the protection of the right occurs through the implementation of the same with the regulatory obligation in terms of the content of the relationship - security. After all, the fulfillment of the obligation after the expiration of the period set for this can no longer be considered appropriate, and the obligation itself should be classified as not being properly performed. In this case, the practical implementation of coercion is possible only through the implementation of harassment, which is part of the protective relationship.

Key words: protective attitude, offense, right to protection. 